\title{
The Effect of Salt Stress on Root Development and Architecture in Common Grasspea (Lathyrus sativus L.)
}

\author{
Harun Bektas ${ }^{1 *}$ \\ ${ }^{1^{*}}$ Siirt University, Faculty of Agriculture, Department of Agricultural Biotechnology, Siirt, Turkey; (ORCID: 0000-0002-4397-4089); bektasharun@gmail.com
}

(First received 30 January 2021 and in final form 23 April 2021)

(DOI: $10.31590 /$ ejosat.871122)

ATIF/REFERENCE: Bektas, H., (2021). The Effect of Salt Stress on Root Development and Architecture in Common Grasspea (Lathyrus sativus L.). European Journal of Science and Technology, (23), 793-799.

\begin{abstract}
Plant root development and architecture are experiencing a period of increased interest due to climate change and increasing drought stress pressure. It is known that root has a 3-dimensional and complex developmental system, just like above-ground organs. Determination of abiotic stress factors affecting root architecture and development in forage legume species is essential for developing abiotic stress-tolerant cultivars and sustainable agricultural production. In this study, it was aimed to investigate the effect of 0 - to 300 $\mathrm{mM}$ salt $(\mathrm{NaCl})$ doses on early root development, root architecture, and endosperm usage ratios in two different common grasspea cultivars (Lathyrus sativus L.) with known basic developmental differences. As a result of the study performed with the modified cigarroll technique, it was observed that in general, 100 to $150 \mathrm{mM}$ and above doses inhibit root growth. The number and length of roots are affected parallel to each other. It was observed that the genotypic differences between the cultivars for the measured parameters related to root development were also reflected in the results. Different cultivars had different levels of tolerance, and the total number and length of roots affect the salt stress inhibition. As a result of the stress encountered in the seedling stage, it was observed that the seed endosperm usage ratio decreased up to 4-fold. It has been observed that evaluation of salt stress tolerance at the seedling stage may shed light on genotypic differences for germination and early development speed, and maybe important for earliness.
\end{abstract}

Keywords: Root architecture; forage legume; $\mathrm{NaCl}$; lateral root development; endosperm usage ratio.

\section{Yaygın Mürdümük (Lathyrus sativus L.) Bitkisinde Tuz Stresinin Kök Gelişimi ve Mimarisine Etkisi}

$\ddot{O} \mathbf{z}$

Bitki kök gelişimi ve mimarisi iklim değişimi ve artan kuraklık baskısı nedeniyle artan bir ilgi ve önem dönemi yaşamaktadır. Kök gelişiminin aynı toprak üstü organların gelişiminde olduğu gibi, 3 boyutlu ve kompleks bir gelişim sistemi olduğu bilinmektedir. Baklagil yem bitkisi türlerinde kök mimarisi ve gelişimini etkileyen abiyotik stress elementlerinin belirlenmesi, abiyotik strese tolerant çeşit geliştirilmesi ve sürdürülebilir tarımsal üretim açısından elzemdir. Bu çalışmada temel gelişimsel farklılıkları bilinen iki farklı mürdümük (Lathyrus sativus L.) çesidinde 0-300 mM arası tuz $(\mathrm{NaCl})$ uygulamasının erken dönem kök gelişimi ve kök mimarisine etkisi ve endosperm kullanım oranının incelenmesi amaçlanmıştır. Modifiye cigar- roll tekniği ile yapılan çalışma sonucunda, genel olarak 100-150 mM ve üstü dozlarının kök gelişimini inhibe ettiği, kök sayı ve uzunluklarının birbirine paralel düzeyde etkilendiği görülmüştür. Kök gelişimi ile ilgili ölçülen parametreler açısından çeşitler arası genotipik farklılıkların, sonuçlara da yansıdığı görülmüş̧ür. Farklı çeşitlerin, farklı düzeylerde toleranslarının olduğu, toplam kök sayısı ve uzunluğunun tuz stresinin etkisini belirgin bir şekilde yansıttığı anlaşılmıştır. Erken dönemde karşılaşılan stress sonucunda tohum endosperm kullanım oranının 4 kata kadar düştüğü görülmüştür. Fide aşamasında tuz stresi toleransı gözleminin çimlenme ve gelişme hızı açısından genotipik farklılıklara 1şık tutabileceği ve erkencilik açısından önemli olduğu gözlemlenmiştir.

Anahtar Kelimeler: Kök mimarisi; baklagil yem bitkisi; NaCl; lateral kök gelişimi; endosperm kullanım oranı. 


\section{Introduction}

Forage crops constitute one of the most important parts of animal production and affect end-user prices significantly (Özyazıcı \& Açıkbaş, 2019a). Common grasspea (Lathyrus sativus L.) is a legume forage plant used in human and animal nutrition (Ahmadi et al., 2015), tolerant to diseases and pests (Talukdar \& Biswas, 2008), and grown for both forage and grain yield (Özyazıcı \& Açıkbaş, 2019b). Grasspea has a known tolerance to drought, cold and moderate salt stress and can be cultivated in diverse climate and soil conditions (Noto et al., 2001; Talukdar, 2011a).

Abiotic stress factors directly threaten food safety and affect production all over the world (Yavaş \& İlker, 2020). Salt stress, one of the abiotic stress factors, is an important problem limiting plant growth, yield, and quality in agricultural production (McMaster \& Wilhelm, 2003). As a result of the accumulation of salt ions in the soil, ion toxicity causes ion imbalances and consequently has negative effects on the yield and quality of the plant growth (Kwon et al., 2019). Besides, the photosynthesis capacity of plants grown in salty conditions decreases depending on the stress level, duration, plant age, and species (Najar et al., 2019). Each plant species reacts differently to salt stress. Sometimes significant differences can arise even between the cultivars of a plant species (Almansouri et al., 2001).

It is known that salt stress affects germination significantly and even completely prevents germination depending on the amount of salt in the soil. It is stated that the most sensitive growth stage to salt stress is germination (Ahmad et al., 2013). It is extremely important that the roots, which are one of the most important parts of the plants, are also significantly affected by salt stress and that the plant has an effective root system for its development.

The effects of salt stress on root architecture in leguminous plants have been demonstrated in some studies (Ariel et al., 2010; Egamberdieva et al., 2017). However, there were no previous reports on the effect of salt stress on common grasspea seedling development and root architecture. In this context, it is thought that this preliminary study may form the basis of future studies. Therefore, this study aimed to evaluate two different common grasspea cultivars for salt stress tolerance with a specific perspective on root development, architecture, and endosperm usage ratio.

\section{Material and Method}

\subsection{Plant Materials and Growth Conditions}

The study was planned to examine the root architectures of common grasspea cultivars under salt stress. It was established in the Laboratory of the Department of Agricultural Biotechnology in Siirt University, in 2020. Common grasspea (Lathyrus sativus L.) cultivars Gürbüz-2001 and GAP mavisi were used as plant materials in the study. The temperature was ranged between $25-$ $27^{\circ} \mathrm{C}$ and the humidity level was $60-70 \%$ as controlled conditions. The study was established according to randomized complete blocks design (RCBD) with three replications and nine plants per replication. The experiment was set up on November 5, 2020 , and was terminated on the $15^{\text {th }}$ day to examine the early development stages.
Seed surface sterilization was carried out in $70 \%$ ethyl alcohol $\left(\mathrm{C}_{2} \mathrm{H}_{5} \mathrm{OH}\right)$ and then in $5 \%$ sodium hypochlorite $(\mathrm{NaCIO})$ for 5 minutes each. The sterilized seeds were rinsed under running water for 1 minute. The seeds were imbibed in water for 24 hours to allow the seeds to germinate homogeneously. The seeds showing homogeneous germination were placed between the germination papers $(40 \times 40 \mathrm{~cm}$ ) as 3 seeds per set (with $10 \mathrm{~cm}$ intervals). Germination papers were turned into cigar rolls and placed in cylindrical containers and left to grow for fifteen days (Zhu et al., 2005). The control treatments had no salt, while salttreated applications had 50, 100, 150, 200, 250, and $300 \mathrm{mM} \mathrm{NaCl}$ concentrations. The amount of water in each container was at the same level and each set received specified salt doses. The experiment was completed at the end of the $15^{\text {th }}$ day and root and shoot growth parameters were measured. To examine the endosperm usage ratio of cultivars under different salt doses, dry seeds were weighted individually before and after the experiments.

\subsection{Root Trait Measurements}

Root samples were scanned in color scale at 600 DPI with a handheld scanner (Iscan Color Mini Portable Scanner). Root images were analyzed using ImageJ (imagej.nih.gov; Schneider et al., 2012) software. In the study, pre-experimental dry seed weight (PreSW), post-experimental dry seed weight (PostSW), shoot length (SL), number of roots (NOR), total root length (TRL), mean total root length (MeanTRL), taproot length (TapRL), number of lateral roots (NLR), total lateral root length (LRL) and mean lateral root length (MeanLRL) parameters were examined (Bektas and Waines, 2020).

\subsection{Statistical Analysis}

Statistical analyses were performed using Statistix 10 software (Analytical Software; Tallahassee, FL, USA) to measure the variation within and between the cultivars with two-way variance analysis (ANOVA). Variance groupings were made using the Least significant Difference (LSD) tests (Steel et al., 1997). Relationships between parameters were examined with Pearson simple correlation analysis.

\section{Results and Discussion}

The effects of salt stress on early root and shoot development in common grasspea cultivars were examined in this study. Two different common grasspea cultivars with different growth characteristics (Özyazıcı \& Açıkbaş, 2019b) were selected (Table 1) for the evaluation. The developmental variation observed between cultivars was effective in salt tolerance levels (Figure 1 and Table 2). According to variance analysis, the effect of seven different salt doses on root development of common grasspea cultivars was significant. Different response levels of the cultivars to salt doses and the cultivar $\mathrm{x}$ salt dose interactions were found statistically significant at the $\mathrm{p}<0.05$ level (Table 2 and 3 ).

Each cultivar had different salt stress tolerance levels at the seedling stage. As the salt dose increased, GAP Mavisi started to be affected at $100 \mathrm{mM}$ salt dose, while Gürbüz-2001 was affected at $150 \mathrm{mM}$ salt dose in terms of total root lengths. It was determined that 0 and $50 \mathrm{mM}$ salt doses did not have a significant effect on root development in both cultivars (Table 2). Total root lengths were determined as $114.57 \mathrm{~cm}$ in GAP Mavisi and 114.02 $\mathrm{cm}$ in Gürbüz-2001 in the control group. At the highest salt dose $(300 \mathrm{mM})$, the total root length in GAP Mavisi was decreased to 
$11.05 \mathrm{~cm}$ and in Gürbüz-2001 to $9.58 \mathrm{~cm}$ (Figure 1). Previous reports suggest weakened above and below ground growth in common grasspea due to salt stress (Talukdar, 2011b; Tsegay and Gebreslassie, 2014). The results of this study suggest that cultivars react to salt stress at different levels and different doses (Figure 1), possibly due to differences in root architecture and various above-ground characteristics. Previously known above and below ground growth differences between these two cultivars were also effective in salt tolerance levels (Data not shown). Determination of the variation in salt stress tolerance within the species could contribute to the development of new cultivars for the specific needs of the salinity-affected regions.

Table 1. Descriptive statistics for the number of roots (NOR), number of lateral roots (NLR), total root length (TRL), lateral root length (LRL), taproot length (TapRL), mean total root length (MeanTRL; TRL/NOR), mean lateral root length (MeanLRL; LRL/NLR), seed weight before (PreSW) and after the experiment (PostSW), root thickness (RT) and shoot length (SL)

\begin{tabular}{llllllllllll}
\hline & Cultivar & NLR & TRL & LRL & Tap RL & $\begin{array}{l}\text { Mean } \\
\text { TRL }\end{array}$ & $\begin{array}{l}\text { Mean } \\
\text { LRL }\end{array}$ & PreSW & PostSW & RT & SL \\
\hline \multirow{2}{*}{ Mean } & GAP Mavisi & 16.76 & 61.78 & 40.31 & 21.41 & 3.29 & 2.11 & 0.14 & 0.08 & 0.17 & 31.05 \\
& Gürbüz-2001 & 16.19 & 56.57 & 35.14 & 21.45 & 2.96 & 1.69 & 0.15 & 0.10 & 0.16 & 29.20 \\
SD & GAP Mavisi & 12.37 & 47.73 & 41.05 & 9.98 & 2.88 & 2.85 & 0.02 & 0.05 & 0.03 & 11.41 \\
& Gürbüz-2001 & 12.19 & 43.99 & 36.21 & 10.44 & 1.84 & 1.31 & 0.02 & 0.05 & 0.02 & 12.65 \\
Variance & GAP Mavisi & 152.89 & 2278 & 1685 & 99.54 & 8.28 & 8.12 & 0.00 & 0.00 & 0.00 & 130.22 \\
& Gürbüz-2001 & 148.65 & 1936 & 1311 & 108.90 & 3.38 & 1.71 & 0.00 & 0.00 & 0.00 & 160.06 \\
\multirow{2}{*}{ SE Mean } & GAP Mavisi & 1.62 & 6.27 & 5.39 & 1.31 & 0.38 & 0.37 & 0.00 & 0.01 & 0.00 & 1.50 \\
& Gürbüz-2001 & 1.60 & 5.78 & 4.75 & 1.37 & 0.24 & 0.17 & 0.00 & 0.01 & 0.00 & 1.66 \\
C.V. & GAP Mavisi & 73.78 & 77.26 & 101.83 & 46.61 & 87.43 & 135.25 & 17.01 & 59.28 & 15.33 & 36.75 \\
\multirow{4}{*}{ Minimum } & Gürbüz-2001 & 75.31 & 77.77 & 103.05 & 48.65 & 62.08 & 77.22 & 13.66 & 52.60 & 14.23 & 43.33 \\
& GAP Mavisi & 0.00 & 0.00 & 0.00 & 0.00 & 0.00 & 0.00 & 0.09 & 0.02 & 0.11 & 4.00 \\
Maximum & Gürbüz-2001 & 0.00 & 4.23 & 0.00 & 4.23 & 0.00 & 0.00 & 0.10 & 0.02 & 0.07 & 3.50 \\
& GAP Mavisi & 54.00 & 212.1 & 186.08 & 36.91 & 21.21 & 20.68 & 0.21 & 0.22 & 0.23 & 52.00 \\
& Gürbüz-2001 & 52.00 & 187.1 & 161.29 & 39.12 & 9.04 & 4.81 & 0.22 & 0.23 & 0.20 & 57.00 \\
\hline
\end{tabular}

SD: Standard deviation, SE Mean: Standard error mean, C.V.: Coefficient of variation

When the total lateral root length was examined, the highest values were found in the control group (GAP Mavisi $85.28 \mathrm{~cm}$, and Gürbüz $79.06 \mathrm{~cm}$ ). It was determined that the differences between the control group and $50 \mathrm{mM}$ in GAP Mavisi and 100 $\mathrm{mM}$ salt dose in Gürbüz-2001 were not significant. Each cultivar was affected differently depending on the salinity level (Figure 1 and Table 2). The first significant effect of salt stress was seen at $150 \mathrm{mM}$ salt dose (Table 3). It is reported that the effect of salt stress on the plant varies according to the dose applied, the time elapsed after salt exposure, and the species (Hasanuzaman et al., 2013; Özkorkmaz and Y1lmaz, 2017). According to the results of the current study, $150 \mathrm{mM}$ salt dose was the critical threshold for both cultivars tested, and plant growth values decreased significantly above this dose. Since this is a preliminary study that examines the early seedling development period, it may be useful to control the upper limit of tolerance in further growth stages and different growth conditions. While $150 \mathrm{mM}$ is a significant limiting threshold in semi-hydroponics culture (Tables 2 and 3), lower or higher doses may be effective in the solid growth medium, such as sand, vermiculite, perlite, or field conditions. Even under field conditions, sowing practices affect avoidable salt and other abiotic stresses (Akdağoğlu et al., 2020). Therefore, there is a need for the evaluation of salt stress tolerance under various growth scenarios. It is planned to examine salt stress and root development interactions under field conditions with the shovelomics technique (Colombi et al., 2015; Burridge et al., 2016).
It was observed that the taproot lengths of the cultivars evaluated were not significantly different between control and 50 $\mathrm{mM}$ doses, and two constituted the first group (Table 2). The highest values were determined in Gürbüz-2001 as 34.95 and $32.95 \mathrm{~cm}$ in the control group and in $50 \mathrm{mM}$ dose, respectively. The lowest values were determined as $10.57 \mathrm{~cm}$ in GAP Mavisi and $9.70 \mathrm{~cm}$ in Gürbüz-2001 at $300 \mathrm{mM}$ salt dose. Even though $300 \mathrm{mM}$ had the lowest values for taproot lengths, the values obtained at $250 \mathrm{mM}$ dose were not significantly different from the highest dose. This similarity suggests that, after a certain threshold, plants can only grow to a limited size. In this parameter, the first significant effect of salt stress was observed at 100 to 150 $\mathrm{mM}$ salt doses (Figure 1 and Table 2). It was observed that 100 and $150 \mathrm{mM}$ had a similar effect on root development, a similar observation was also seen between 250 and $300 \mathrm{mM}$ doses. Here, $250 \mathrm{mM}$ and above was perceived as a very high dose for common grasspea taproot initiation, and the taproot remained at one-third of the size compared to optimum development (control group). High levels of salt stress not only restricted lateral roots, but also the taproot, and as a result, the taproot remained very short compared to normal growth. The shortened taproot may cause the plant to have limited access to deep water layers in the soil during summer droughts and the plant may not survive the dry season. As a result, even short-term salt stress may cause the plant to fall behind its survival potential. Salt stress at early growth stages may have a limiting effect on plant productivity and product quality (Koca et al., 2007). 
Mean lateral root length highlights, plant's overall ability in rooting. It was determined that the least affected cultivar was the GAP Mavisi with a mean lateral root length of $4.49 \mathrm{~cm}$ at $100 \mathrm{mM}$ salt dose. The control group and $100 \mathrm{mM}$ dose were statistically in the same group for GAP Mavisi. Depending on the effect of salt, the lowest mean lateral root length values were obtained in Gürbüz-2001 with $0.62 \mathrm{~cm}$ at $250 \mathrm{mM}$ salt dose, and in both cultivars at $300 \mathrm{mM}$ salt dose (Tables 2 and 3). The mean lateral root length is a parameter that reveals the rooting potential of the plant in terms of number and length. The decrease in the mean value from $4.49 \mathrm{~cm}$ to $0.62 \mathrm{~cm}$ indicates that the plants' photosynthesis, respiration, and carbon circulation are significantly interrupted under salt stress. The negative interactions of the seed's final weight with the increased salt dose also shown that even the stocks in the endosperm cannot be used under salt stress. There was a 4-fold difference in seed final weight between control and $300 \mathrm{mM}$ dose.

Although it is known that salt stress affects plant growth negatively, there is no study reporting its effect on the seedling root architecture of common grasspea. Talukdar (2011a) reported that low salt doses had a similar effect on root growth and higher doses led to a significant inhibition.

Table 2. Genotype x dose interactions for the cultivars GAP Mavisi and Gürbüz-2001 for total root length (TRL), lateral root length $(L R L)$, taproot length (TapRL), mean lateral root length (MeanLRL; LRL/NLR), root thickness (RT), shoot length (SL), number of roots (NOR), number of lateral roots (NLR) and seed weight after the experiment (Post $S W$ )

\begin{tabular}{rllllllllll}
\hline Dose & Genotype & TRL & LRL & TapRL & Mean LRL & RT & SL & NOR & NLR & Post SW \\
\hline \multirow{2}{*}{0} & GAPMavisi & $114.57 \mathrm{a}$ & $85.28 \mathrm{a}$ & $29.30 \mathrm{a}-\mathrm{c}$ & $3.20 \mathrm{ab}$ & $0.19 \mathrm{a}$ & $40.78 \mathrm{ab}$ & $31.11 \mathrm{a}$ & $30.11 \mathrm{a}$ & $0.04 \mathrm{fg}$ \\
& Gürbüz-2001 & $114.02 \mathrm{a}$ & $79.06 \mathrm{ab}$ & $34.95 \mathrm{a}$ & $3.05 \mathrm{a}-\mathrm{c}$ & $0.17 \mathrm{a}-\mathrm{d}$ & $44.53 \mathrm{a}$ & $27.27 \mathrm{ab}$ & $26.27 \mathrm{ab}$ & $0.03 \mathrm{~g}$ \\
50 & GAPMavisi & $94.45 \mathrm{ab}$ & $63.28 \mathrm{ab}$ & $30.78 \mathrm{ab}$ & $2.50 \mathrm{~b}-\mathrm{d}$ & $0.18 \mathrm{ab}$ & $37.22 \mathrm{a}-\mathrm{c}$ & $26.56 \mathrm{ab}$ & $25.56 \mathrm{ab}$ & $0.05 \mathrm{e}-\mathrm{g}$ \\
& Gürbüz-2001 & $89.34 \mathrm{ab}$ & $56.87 \mathrm{bc}$ & $32.59 \mathrm{a}$ & $2.58 \mathrm{~b}-\mathrm{d}$ & $0.16 \mathrm{~b}-\mathrm{d}$ & $37.69 \mathrm{a}-\mathrm{c}$ & $24.52 \mathrm{ab}$ & $23.51 \mathrm{ab}$ & $0.10 \mathrm{~b}-\mathrm{d}$ \\
\multirow{2}{*}{100} & GAPMavisi & $77.61 \mathrm{bc}$ & $56.15 \mathrm{bc}$ & $21.45 \mathrm{~d}-\mathrm{f}$ & $4.49 \mathrm{a}$ & $0.17 \mathrm{a}-\mathrm{c}$ & $35.83 \mathrm{a}-\mathrm{c}$ & $15.11 \mathrm{c}-\mathrm{e}$ & $14.11 \mathrm{c}-\mathrm{e}$ & $0.07 \mathrm{~d}-\mathrm{f}$ \\
& Gürbüz-2001 & $93.43 \mathrm{ab}$ & $67.76 \mathrm{ab}$ & $25.68 \mathrm{~b}-\mathrm{d}$ & $2.52 \mathrm{~b}-\mathrm{d}$ & $0.17 \mathrm{a}-\mathrm{d}$ & $31.35 \mathrm{c}-\mathrm{e}$ & $25.67 \mathrm{ab}$ & $24.67 \mathrm{ab}$ & $0.08 \mathrm{c}-\mathrm{e}$ \\
\multirow{2}{*}{150} & GAPMavisi & $57.83 \mathrm{~cd}$ & $34.13 \mathrm{~cd}$ & $23.69 \mathrm{c}-\mathrm{e}$ & $1.62 \mathrm{~b}-\mathrm{e}$ & $0.16 \mathrm{~b}-\mathrm{d}$ & $33.17 \mathrm{~b}-\mathrm{d}$ & $20.56 \mathrm{bc}$ & $19.56 \mathrm{bc}$ & $0.08 \mathrm{c}-\mathrm{e}$ \\
& Gürbüz-2001 & $35.61 \mathrm{de}$ & $16.94 \mathrm{de}$ & $18.64 \mathrm{e}-\mathrm{g}$ & $1.48 \mathrm{~b}-\mathrm{e}$ & $0.16 \mathrm{~b}-\mathrm{d}$ & $26.17 \mathrm{~d}-\mathrm{f}$ & $11.00 \mathrm{~d}-\mathrm{f}$ & $10.00 \mathrm{~d}-\mathrm{f}$ & $0.11 \mathrm{bc}$ \\
200 & GAPMavisi & $30.14 \mathrm{e}$ & $13.98 \mathrm{de}$ & $16.16 \mathrm{f}-\mathrm{h}$ & $1.01 \mathrm{c}-\mathrm{e}$ & $0.15 \mathrm{~cd}$ & $23.00 \mathrm{e}-\mathrm{g}$ & $11.67 \mathrm{~d}-\mathrm{f}$ & $10.67 \mathrm{~d}-\mathrm{f}$ & $0.10 \mathrm{~b}-\mathrm{d}$ \\
& Gürbüz-2001 & $34.27 \mathrm{de}$ & $15.64 \mathrm{de}$ & $18.66 \mathrm{e}-\mathrm{g}$ & $0.87 \mathrm{de}$ & $0.17 \mathrm{a}-\mathrm{d}$ & $26.10 \mathrm{~d}-\mathrm{g}$ & $18.67 \mathrm{~b}-\mathrm{d}$ & $17.67 \mathrm{~b}-\mathrm{d}$ & $0.12 \mathrm{ab}$ \\
& GAPMavisi & $19.62 \mathrm{e}$ & $6.53 \mathrm{e}$ & $13.11 \mathrm{~h}$ & $0.74 \mathrm{de}$ & $0.17 \mathrm{a}-\mathrm{d}$ & $19.28 \mathrm{fg}$ & $8.47 \mathrm{ef}$ & $7.61 \mathrm{ef}$ & $0.15 \mathrm{a}$ \\
& Gürbüz-2001 & $19.02 \mathrm{e}$ & $7.95 \mathrm{e}$ & $11.10 \mathrm{~h}$ & $0.62 \mathrm{e}$ & $0.16 \mathrm{~b}-\mathrm{d}$ & $20.78 \mathrm{fg}$ & $9.78 \mathrm{ef}$ & $8.78 \mathrm{ef}$ & $0.13 \mathrm{ab}$ \\
\multirow{2}{*}{300} & GAPMavisi & $11.05 \mathrm{e}$ & $0.55 \mathrm{e}$ & $10.57 \mathrm{~h}$ & $0.21 \mathrm{e}$ & $0.17 \mathrm{a}-\mathrm{d}$ & $21.53 \mathrm{fg}$ & $4.21 \mathrm{f}$ & $3.2 \mathrm{f}$ & $0.10 \mathrm{~b}-\mathrm{d}$ \\
& Gürbüz-2001 & $9.58 \mathrm{e}$ & $0.39 \mathrm{e}$ & $9.70 \mathrm{~h}$ & $0.11 \mathrm{e}$ & $0.14 \mathrm{~d}$ & $16.95 \mathrm{~g}$ & $2.71 \mathrm{f}$ & $1.7 \mathrm{f}$ & $0.13 \mathrm{ab}$ \\
\hline
\end{tabular}

Means followed by different letters within columns are different according to the least significant difference (LSD) test at $p<0.05$

Although the effect of salt stress on root thickness in common grasspea was statistically significant, it was observed that it followed a fluctuating as higher doses were applied. While the highest value was determined in the control group as $0.19 \mathrm{~cm}$ in GAP Mavisi, the lowest value was found in Gürbüz-2001 as 0.11 $\mathrm{cm}$ at $300 \mathrm{mM}$ salt dose (Table 2). Although the effect of root thickness by salt dose was significant between control and 300 $\mathrm{mM}$, no dose-dependent interaction was observed. The reason for this may be the small number of cultivars or the duration of the experiment or some other complex interaction. The extent to which the root diameter changes according to environmental conditions, the level of inheritance, and its effects on this parameter should be revealed with comprehensive studies. No similar studies were found in common grasspea or related species.

Shoot length variation under salt stress is also evaluated for two cultivars. Gürbüz-2001 was the least affected in the control group with a value of $44.53 \mathrm{~cm}$. Along with this cultivar, the GAP Mavisi had a gradual decrease in shoot length as the salt dose increased. There were significant, but relatively small reductions between control, 50, and $100 \mathrm{mM}$ doses (Figure 1). The salt doses

Table 3. The effect of salt dose in mean values for total root length (TRL), lateral root length (LRL). taproot length (TapRL), mean total root length (MeanTRL; TRL/NOR), mean lateral root length (MeanLRL; LRL/NLR), root thickness (RT), shoot length (SL), number of roots (NOR), number of lateral roots (NLR), and seed weight after the experiment (PostSW)

\begin{tabular}{rlllcclllll}
\hline Dose & TRL & LRL & TapRL & Mean TRL & Mean LRL & RT & SL & NOR & NLR & Post SW \\
\hline 0 & $114.29 \mathrm{a}$ & $82.17 \mathrm{a}$ & $32.12 \mathrm{a}$ & $4.25 \mathrm{a}$ & $3.12 \mathrm{a}$ & $0.18 \mathrm{a}$ & $42.65 \mathrm{a}$ & $29.19 \mathrm{a}$ & $28.19 \mathrm{a}$ & $0.03 \mathrm{~d}$ \\
50 & $91.9 \mathrm{~b}$ & $60.07 \mathrm{~b}$ & $31.68 \mathrm{a}$ & $3.74 \mathrm{a}$ & $2.54 \mathrm{ab}$ & $0.17 \mathrm{ab}$ & $37.46 \mathrm{ab}$ & $25.54 \mathrm{ab}$ & $24.54 \mathrm{ab}$ & $0.08 \mathrm{c}$ \\
100 & $85.52 \mathrm{~b}$ & $61.95 \mathrm{~b}$ & $23.57 \mathrm{~b}$ & $4.49 \mathrm{a}$ & $3.5 \mathrm{a}$ & $0.17 \mathrm{ab}$ & $33.59 \mathrm{bc}$ & $20.39 \mathrm{bc}$ & $19.39 \mathrm{bc}$ & $0.08 \mathrm{c}$ \\
150 & $46.72 \mathrm{c}$ & $25.54 \mathrm{c}$ & $21.17 \mathrm{bc}$ & $3.19 \mathrm{ab}$ & $1.55 \mathrm{bc}$ & $0.16 \mathrm{~b}$ & $29.67 \mathrm{~cd}$ & $15.78 \mathrm{c}$ & $14.78 \mathrm{c}$ & $0.09 \mathrm{bc}$ \\
200 & $32.2 \mathrm{~cd}$ & $14.81 \mathrm{~cd}$ & $17.39 \mathrm{c}$ & $2.16 \mathrm{bc}$ & $0.94 \mathrm{c}$ & $0.16 \mathrm{~b}$ & $24.53 \mathrm{de}$ & $15.17 \mathrm{~cd}$ & $14.17 \mathrm{~cd}$ & $0.11 \mathrm{~b}$ \\
250 & $19.32 \mathrm{de}$ & $7.24 \mathrm{~cd}$ & $12.11 \mathrm{~d}$ & $1.64 \mathrm{c}$ & $0.68 \mathrm{c}$ & $0.16 \mathrm{ab}$ & $20.03 \mathrm{e}$ & $9.12 \mathrm{de}$ & $8.2 \mathrm{de}$ & $0.14 \mathrm{a}$ \\
300 & $10.32 \mathrm{e}$ & $0.24 \mathrm{~d}$ & $10.12 \mathrm{~d}$ & $1.8 \mathrm{bc}$ & $0.16 \mathrm{c}$ & $0.16 \mathrm{~b}$ & $19.24 \mathrm{e}$ & $3.46 \mathrm{e}$ & $2.45 \mathrm{e}$ & $0.12 \mathrm{ab}$ \\
\hline
\end{tabular}

Means followed by different letters within columns are different according to the least significant difference (LSD) test at $\mathrm{p}<0.05$ 
showed different effects on the cultivars in terms of shoot growth. While salt showed its first significant effect on Güzbüz-2001 at $100 \mathrm{mM}$, it started to affect GAP Mavisi at $150 \mathrm{mM}$ (Table 2) in shoot length. The sharpest effect of salt stress was observed in Gürbüz-2001 with a value of $16.95 \mathrm{~cm}$ shoot length at $300 \mathrm{mM}$ dose. Considering that the shoot and root growth are significantly correlated (Bektas, 2015), and root growth is significantly affected from 100 to $150 \mathrm{mM}$ doses, shoot growth is followed a similar trend.

When the cultivars were evaluated for the total number of roots, the highest mean values were found in GAP Mavisi with

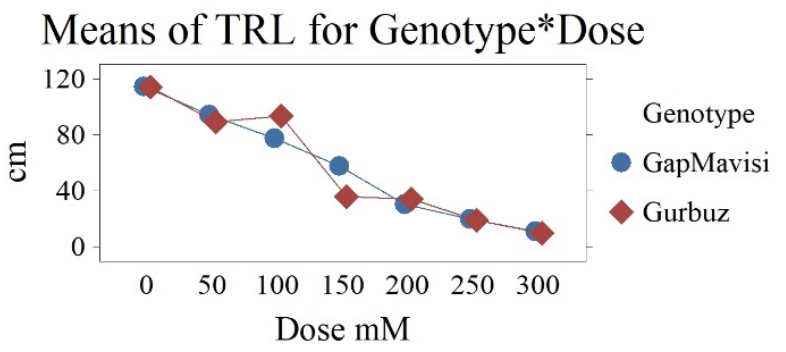

Means of TapRL for Genotype*Dose

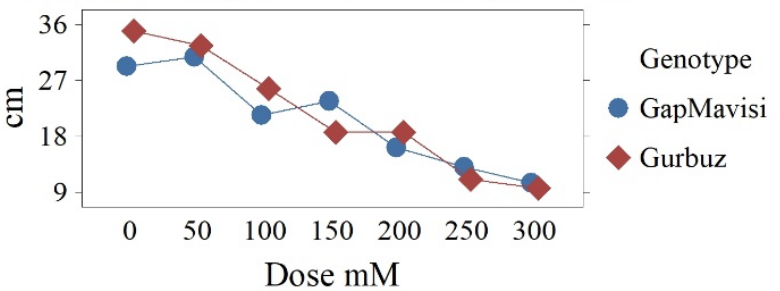

Means of MeanLRL for Genotype*Dose

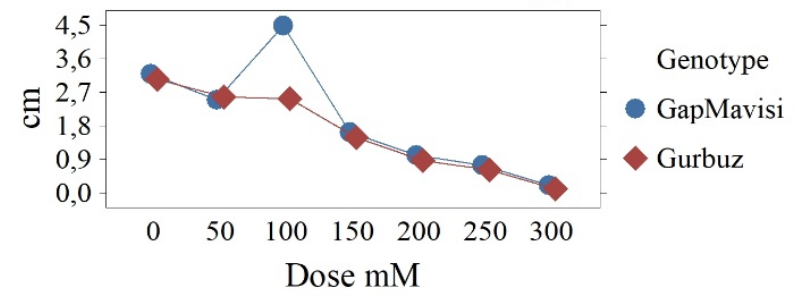

Means of RootThick for Genotype*Dose

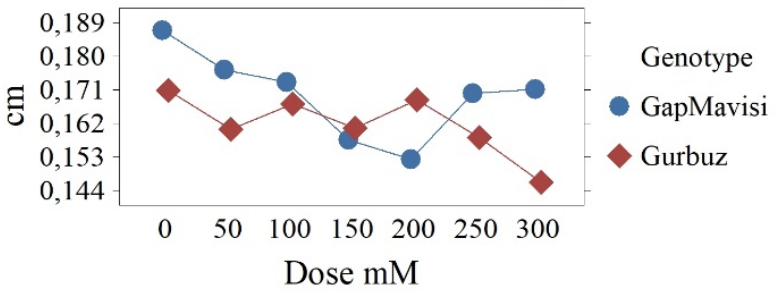

Means of NLR for Genotype*Dose

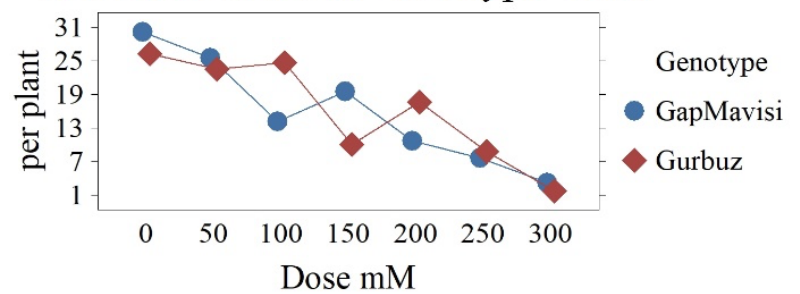

31.11 roots per plant in the control group. The lowest values were determined as 4.21 and 2.71 under $300 \mathrm{mM}$ salt dose. The first significantly limiting salinity level was $100 \mathrm{mM}$ for GAP Mavisi and 150mM for Gürbüz-2001 (Figure 1 and Table 2). Increasing salt dose is thought to inhibit lateral root development and root differentiation from root epithelial cells. This directly effects features that determines the fate of the plant in both water and mineral uptake, such as total root length. Evaluation of the number and length of roots of a cultivar under salt stress is important to reveal the performance of the plant under stress, even though each genotype has a genetic potential for the number of roots.

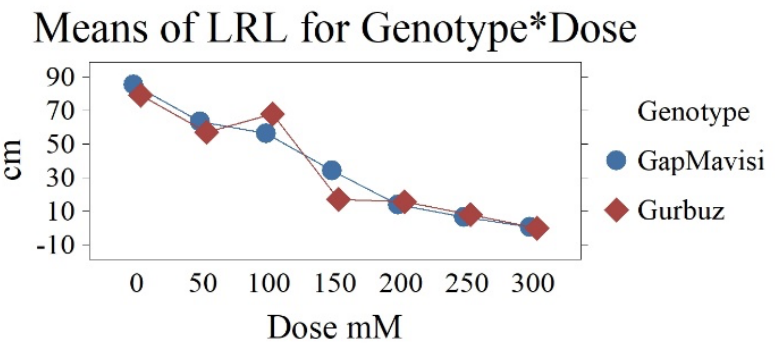

Means of MeanTRL for Genotype*Dose

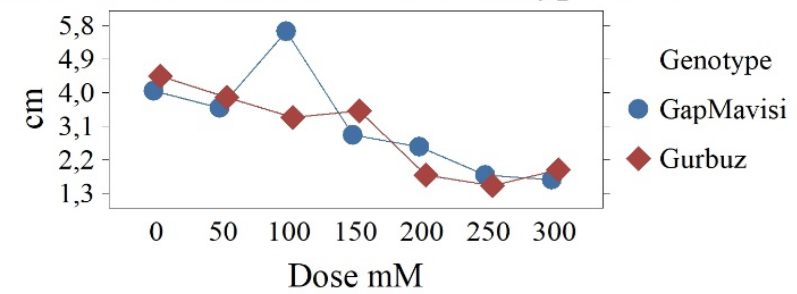

Means of SL for Genotype*Dose

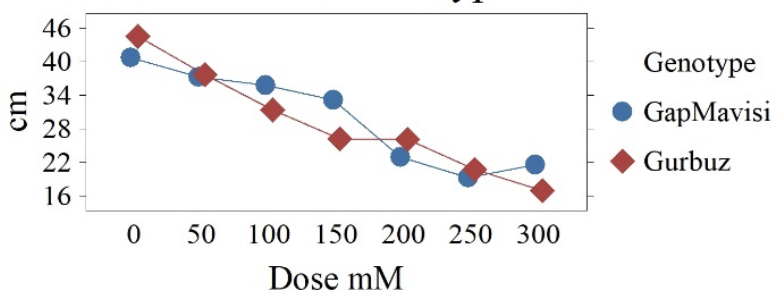

Means of NOR for Genotype*Dose

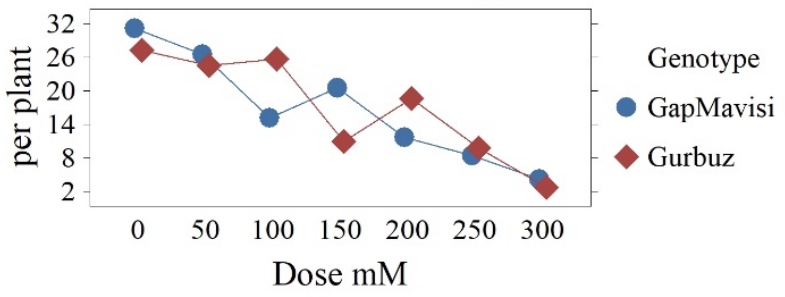

Means of PostSW for Genotype*Dose

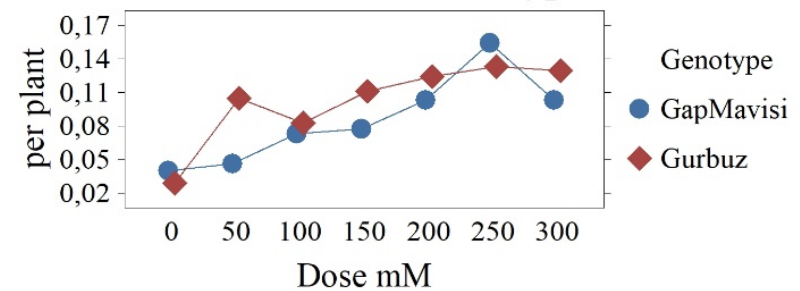

Figure 1. Changes in mean values for total root length (TRL), lateral root length (LRL), taproot length (TapRL), mean total root length (MeanTRL; TRL/NOR), mean lateral root length (MeanLRL; LRL/NLR), shoot length (SL), root thickness (RT), number of roots (NOR), number of lateral roots (NLR), and seed weight after the experiment (PostSW) 
The effects of salt stress on the number of lateral roots in common grasspea cultivars were observed at a salt dose of 150 $\mathrm{mM}$ for Gürbüz-2001, while it was observed at $100 \mathrm{mM}$ dose in GAP Mavisi (Figure 1 and Table 2). Although no similar studies were investigating the relationship between root architecture and salt stress, Önal Aşçı and Zambi (2020), stated that salt doses up to $150 \mathrm{mM}$ negatively affected root biomass, number of leaves, and above-ground biomass in pea (Pisum sativum L.). Considering that root biomass and the number of roots is two correlated traits, the results in this study were comparable with the previous report.

Pre (PreSW) and post-experimental dry seed weights (PostSW) were also examined in this study. It was seen that the PostSW was increased as the salt dose increased and the highest PostSW values were at $250 \mathrm{mM}$ and $300 \mathrm{mM}$ salt doses (Table 2). The lowest values were found in the control group. According to these data, it was concluded that the endosperm usage ratio was reduced due to increasing salt doses. Under salt stress, the seedlings could not use the endosperm stocks and as a result, early root development progressed slowly. Similar results were observed in both cultivars with very similar pre-experimental seed weights (Figure 1). A similar study in another legume species
(Pisum sativum arvense) has been shown to have different endosperm utilization rates (Semih Acikbas, personnel communication) between cultivars during the same growth day. However, the endosperm utilization rates of different cultivars under salt stress have been shown for the first time in common grasspea with this study. As the salt dosage increased in both cultivars, PostSW was increased, but the ratios were different. The cultivar with a higher salt tolerance level used a higher proportion of its endosperm compared to the cultivar with a lower tolerance level.

To examine the relationships between seedling root traits, the correlation (Pearson) test was applied, and a high level of correlation was found between the root parameters. A positive correlation was observed between taproot length and, the total number of roots $(0.74)$, the number of lateral roots $(0.74)$, total root length (0.75), and total lateral root length (0.63) (Table 4). Besides, a negative correlation was determined ( -0.34 to -0.63$)$ between dry seed weight (PostSW) and all root traits (Table 4). As a result of this study, it was seen that root development proceeds with a system logic (Lynch, 2013) and there is correlated developmental progress that forms the basic architectural structure among all root parameters.

Table 4. Correlations (Pearson) coefficients between the number of roots (NOR), number of lateral roots (NLR), total root length (TRL), lateral root length (LRL), taproot length (TapRL), mean total root length (MeanTRL; TRL/NOR), mean lateral root length (MeanLRL; $L R L / N L R)$, seed weight before (PreSW) and after (PostSW) the experiment, root thickness (RT), and shoot length (SL).

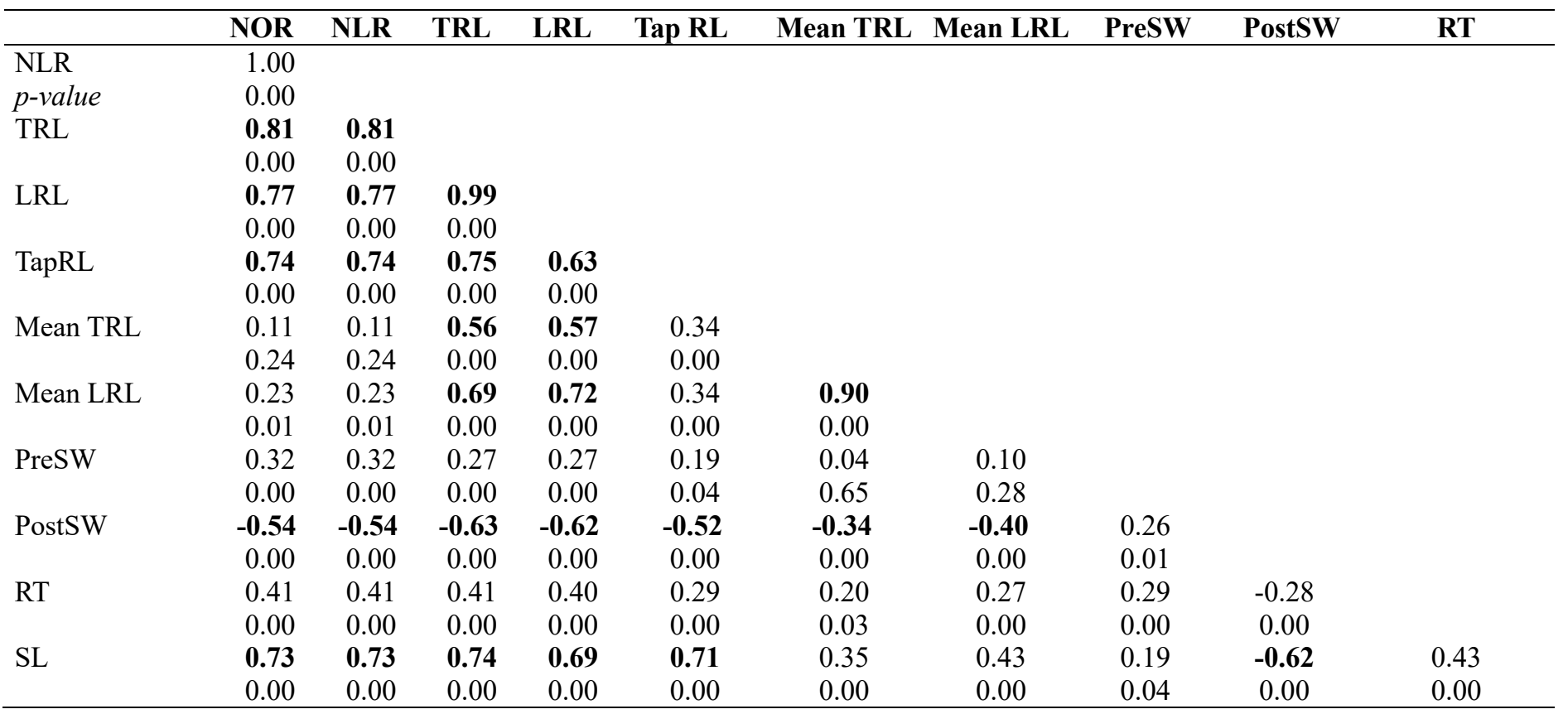

\section{Conclusions and Recommendation}

Identification of the changes in the root architecture of cultivars with different root characteristics under salt stress is an important outcome to understand plant growth under abiotic stress. Further studies examining different genotypes under controlled and field conditions are important in terms of

\section{Acknowledgements}

The author is grateful to Semih Acikbas for his help with experiments and measurements. understanding root architecture and universal responses to salt stress in legume species. This preliminary study aimed to examine the root development patterns of common grasspea cultivars under salt stress. An average of $100-150 \mathrm{mM}$ salt dose seems to be the threshold for growth limitation in the root system and salt tolerance in common grasspea seedlings. The salt stress tolerance thresholds should be revealed with further studies and species to breed cultivars with higher tolerance rates.

Conflict of interest: The author declares no conflict of interest. 


\section{References}

Ahmad, P., Azooz, M. M., \& Prasad, M. N. V. (2013). Salt stress in plants. Heidelberg: Springer.

Ahmadi, J., Vaezi, B., \& Pour-Aboughadareh, A. (2015). Assessment of heritability and relationships among agronomic characters in grass pea (Lathyrus sativus L.) under rainfed conditions. Biharean Biologist, 9(1), 29-34.

Akdağoğlu, M., Bayhan, Y.,\& Baran, M.F. (2020). II. Ürün Ayçiçeği Üretiminde Farklı Toprak İşleme Yöntemlerinin Teknik Olarak Değerlendirilmesi. European Journal of Science and Technology, (20), 334-342.

Almansouri, M., Kinet, J. M., \& Lutts, S. (2001). Effect of salt and osmotic stresses on germination in durum wheat (Triticum durum Desf.). Plant and Soil, 231(2), 243-254.

Ariel, F. D., Diet, A., Crespi, M., \& Chan, R. L. (2010). The LOBlike transcription factor MtLBD1 controls Medicago truncatula root architecture under salt stress. Plant Signaling \& Behavior, 5(12), 1666-1668.

Bektaş, H., \& Waines, J.G. (2020). Effect of Grain Size on The Root System Architecture of Bread Wheat (Triticum aestivum L.). Türkiye Tarımsal Araştırmalar Dergisi, 7(1), 78-84.

Bektas, H. (2015). Determination of Root Traits in Wild, Landrace and Modern Wheats and Dissection of Quantitative Trait Loci (QTL) for Root Characters in Bread Wheat (Doctoral dissertation, UC Riverside).

Burridge, J., Jochua, C. N., Bucksch, A., \& Lynch, J. P. (2016). Legume shovelomics: high-throughput phenotyping of common bean (Phaseolus vulgaris L.) and cowpea (Vigna unguiculata subsp, unguiculata) root architecture in the field. Field Crops Research, 192, 21-32.

Colombi, T., Kirchgessner, N., Le Marié, C. A., York, L. M., Lynch, J. P., \& Hund, A. (2015). Next generation shovelomics: set up a tent and REST. Plant and Soil, 388(1), $1-20$.

Egamberdieva, D., Wirth, S. J., Shurigin, V. V., Hashem, A., \& Abd_Allah, E. F. (2017). Endophytic bacteria improve plant growth, symbiotic performance of chickpea (Cicer arietinum L.) and induce suppression of root rot caused by Fusarium solani under salt stress. Frontiers in Microbiology, 8, 1887.

Hasanuzzaman, M., Nahar, K., \& Fujita, M. (2013). Plant response to salt stress and role of exogenous protectants to mitigate salt-induced damages. In Ecophysiology and responses of plants under salt stress (pp. 25-87). Springer, New York, NY.

Koca, H., Bor, M., Özdemir, F., \& Türkan, İ. (2007). The effect of salt stress on lipid peroxidation, antioxidative enzymes and proline content of sesame cultivars. Environmental and experimental Botany, 60(3), 344-351.

Kwon, O. K., Mekapogu, M., \& Kim, K. S. (2019). Effect of salinity stress on photosynthesis and related physiological responses in carnation (Dianthus caryophyllus). Horticulture, Environment, and Biotechnology, 60(6), 831-839.

Lynch, J. P. (2013). Steep, cheap and deep: an ideotype to optimize water and $\mathrm{N}$ acquisition by maize root systems. Annals of botany, 112(2), 347-357.

McMaster, G. S., \& Wilhelm, W. (2003). Phenological responses of wheat and barley to water and temperature: improving simulation models. Journal of Agricultural Science, 141, 129147.

Najar, R., Aydi, S., Sassi-Aydi, S., Zarai, A., \& Abdelly, C. (2019). Effect of salt stress on photosynthesis and chlorophyll fluorescence in Medicago truncatula. Plant Biosystems, 153(1), 88-97.

Noto, F., Poma, I., Gristina, L., Venezia, G., \& Ferrotti, F. (2001). Bioagronomic and qualitative characteristics in Lathyrus sativus lines. In Proceedings 4th European Conference on Grain Legumes (eds. AEP) (pp. 8-12). Cracow, Poland.

Önal Aşçı, Ö., \& Zambi, H. (2020). Farklı $\mathrm{NaCl}$ konsantrasyonlarının bazı bezelye çeşit ve genotiplerinde bitki gelişimine etkisi. Anadolu Tarım Bilimleri Dergisi, 35(3), 274-284.

Özkorkmaz, F., \& Y1lmaz, N. (2017). Farklı tuz konsantrasyonlarının fasulye (Phaseolus vulgaris L.) ve börülcede (Vigna unguiculata L.) çimlenme üzerine etkilerinin belirlenmesi. Ordu Üniversitesi Bilim ve Teknoloji Dergisi, 7(2), 196-200.

Özyazıcı, M.A., \& Açıkbaş, S. (2019a). Koca Fiğ (Vicia narbonensis L.) Bitkisinde Fosforlu Gübre Dozlarının Ot ve Tohum Verimine Etkisi. Avrupa Bilim ve Teknoloji Dergisi, (17), 1031-1036.

Özyazıcı, M. A., \& Açıkbaş, S. (2019b). Yaygın Mürdümük (Lathyrus sativus L.) Genotiplerinin Yarı Kurak İklim Koşullarında Bazı Tarımsal Özellikleri ile Verim Performanslarının Belirlenmesi. Avrupa Bilim ve Teknoloji Dergisi, (17), 1058-1068.

Schneider, C. A., Rasband, W. S., \& Eliceiri, K. W. (2012). NIH Image to ImageJ: 25 years of image analysis. Nature methods, 9(7), 671-675.

Steel, R.G.D., Torrie, J.H., \& Dickey, D.A. (1997). Principles and procedures of statistics: a biometrical approach. New York: McGraw-Hill; 1997.

Talukdar, D., \& Biswas, A. K. (2008). Variability, heritability and scope of selection for some quantitative traits in induced mutant lines of grass pea (Lathyrus sativus L.). International Journal of Plant Sciences, 3(2), 528-530.

Talukdar, D. (2011a). Morpho-physiological responses of grass pea (Lathyrus sativus L.) genotypes to salt stress at germination and seedling stages. Legume Research, 34(4), 232-241.

Talukdar, D. (2011b). Flower and pod production, abortion, leaf injury, yield and seed neurotoxin levels in stable dwarf mutant lines of grass pea (Lathyrus sativus L.) differing in salt stress responses. International Journal of Current Research, 2(1), 46-54.

Tsegay, B. A., \& Gebreslassie, B. (2014). The effect of salinity $(\mathrm{NaCl})$ on germination and early seedling growth of Lathyrus sativus and Pisum sativum var. abyssinicum. African Journal of Plant Science, 8(5), 225-231.

Yavaş, İ., \& İlker, E. (2020). Çevresel Stres Koşullarına Maruz Kalan Bitkilerde Fotosentez ve Fitohormon Seviyelerindeki Değişiklikler. Bahri Dağdaş Bitkisel Araştırma Dergisi, 9(2), 295-311.

Zhu, J., Kaeppler, S. M., \& Lynch, J. P. (2005). Mapping of QTLs for lateral root branching and length in maize (Zea mays L.) under differential phosphorus supply. Theoretical and Applied Genetics, 111(4), 688-695. 